\title{
REVISTAMARACANAN
}

Artigos

\section{"A tirania da moda": roupas, comércio e consumo no Rio de Janeiro do século XIX ${ }^{1}$}

\author{
"The tyranny of fashion": clothing, trade and consumption \\ in Rio de Janeiro of the nineteenth century
}

\author{
Joana de Moares Monteleone \\ Universidade Federal de São Paulo \\ joana@alamedaeditorial.com.br
}

\begin{abstract}
Resumo: No século XIX, a moda movimentou a economia do Rio de Janeiro. Ao trazer novas ideias e novos hábitos de sociabilidade e distinção social, a moda movimentou uma grande quantidade de recursos. O maior tipo de produto exportado para o Brasil não eram roupas prontas, mas sim tecidos das mais variadas espécies, catalogados pela alfândega do Rio. Esses tecidos eram transformados em roupas em ateliês, os mais chiques, localizados na rua do Ouvidor. Neste artigo, se entrelaçam uma análise sobre o estabelecimento da moda e do consumo na Corte e uma leitura explicativa das estatísticas de importação de tecidos que entravam pelo porto do Rio de Janeiro.
\end{abstract}

Palavras-chave: Moda; Consumo; Tecidos; Império; Século XIX.

Abstract: In the nineteenth century, the fashion moves the economy of Rio de Janeiro. By bringing new ideas and sociability habits and social distinction, fashion moved a lot of resources. The largest type of product exported to Brazil were not ready-made clothes, but the most varied species tissues, cataloged by the customs of Rio that were transformed into clothes by little shops in Ouvidor Street. In this article, there is an analysis of the establishment of fashion and consumption at court and an explanatory reading of the importation statistics tissues that entered the port of Rio de Janeiro.

Keywords: Fashion; Consume; Fabrics; Empire; XIX century.

Artigo recebido para publicação em: Fevereiro de 2016

Artigo aprovado para publicação em: Abril de 2016

\footnotetext{
${ }^{1}$ Esta pesquisa recebeu financiamento da Capes.
} 
"Assim, não é, pois, mais indiferente desprezar ou adotar as fugidias prescrições da moda, pois mens agitat molem: o espírito de um homem advinha-se pela maneira como porta sua bengala. [...] Como a roupa é o mais enérgico de todos os símbolos, a Revolução foi também uma questão de moda, um debate entre seda e lã." (Honoré de Balzac) ${ }^{2}$

m meados do século XVIII, o escritor inglês Daniel Defoe (1660-1731) observou
um fenômeno novo e o descreveu em seu último livro, The complete english
tradesman. Espantado, Defoe fala de uma nova atitude em seu tempo:

[...] certas damas, e também pessoas de grande pompa, têm tomado as suas carruagens e passado uma tarde inteira em Ludgate Street, ou em Covent Garden, apenas para divertir-se indo de uma a outra loja, para olhar as sedas, tagarelar e zombar dos comerciantes, não tendo tanto como a menor ocasião, muito menos intenção de comprar qualquer coisa. ${ }^{3}$

No mesmo período em que Daniel Defoe escreveu seu romance, em Portugal a palavra moda ganhava uma definição, um verbete no dicionário, que ainda era ambíguo e misturava os dois tempos: o tempo das roupas feitas para durar e o das novidades constantemente renovadas. O dicionário de Rapahel Bluteau, editado em Lisboa entre 1712 e 1724, vem com uma longa definição, reproduzida abaixo:

Moda: o modo de trajar, falar ou fazer qualquer coisa conforme o costume novamente introduzido. Antigamente não havia modos no trajo como nem ainda hoje as há em todo o Levante. Parece razoável a continuação desta uniformidade no vestir, porque os vestidos se fizeram para cobrir o corpo, e como todos os corpos humanos, em todo o tempo são na figura os mesmos, é muito para estranhar a prodigiosa mudança de vestiduras, que umas às outras continuamente se seguem. E assim os inventores das modas, não são a gente mais sisuda da República; ordinariamente são mulheres e moços do Norte incitados por mercadores e artífices que não tem outro fim que a própria conveniência. Esta perpetua a variedade de ornatos não deixa de ter perniciosas consequências; os que a não seguem parecem ridículos, os que com ela se conformam, desperdiçam patrimônios. Os antigos, como sempre seguiam no vestir o mesmo estilo, sendo ricos, tinham quantidade de vestidos sobressalentes. No livro I das Epift. Horácio, se vê que no seu guarda-roupa tinha. Lucullo cinco mil chamydes, que entre romanos era um sago ou jaleca militar; desta abundância se pode julgar o mais. Quando o vestido é cômodo para o uso do corpo, descente para a qualidade e bom contra as injúrias do tempo; o inventar outro parece loucura, que bizarria. Aquiles Estaco dá a entender que no seu tempo os romanos introduziram, novas modas do vestir. ${ }^{4}$ (Grifo do autor)

\footnotetext{
2 BALZAC, Honoré de. "Tratado da vida elegante". In: Manual do dândi, a vida com estilo. Tomaz Tadeu (Org). Belo Horizonte: Autêntica, 2009. p. 47.

3 DEFOE, Daniel. The complete english tradesman. Nova York: Penguin, 1983. p. 312.

4 Dicionário Rapahel Bluteau, verbete "moda". Disponível em: IEB, www.ieb.usp.br.
} 
O texto é interessante para percebemos as sutilezas da palavra moda, que, na época, ainda estava por se estabelecer como um fenômeno social. Trocar constantemente de roupas era considerado uma extravagância, um hábito de pessoas do "norte", jovens inconsequentes que não viam o bom senso de boas roupas duradouras. Mas essa era uma definição que estava para mudar e, ao longo do século XVIII, a noção de moda, ou mesmo de estar na moda, se transformou radicalmente.

Cerca de um século mais tarde, em 1813, o dicionário Moraes \& Silva, de Antonio Moraes Silva, publicava a seguinte definição: "moda: o uso correto e adotado de vestir, trajar em certas maneiras, gostos, estudos e exercício". ${ }^{5}$ Sucinto, o dicionarista já revelava o uso mais amplo e contemporâneo para a palavra, que vinha ligada às roupas e às maneiras de se portar em sociedade.

A Revolução Industrial intensificou um fenômeno que já vinha de antes, do aumento da procura e do consumo de itens ligados ao vestuário e às intensificações das medidas legislativas relativas às leis suntuárias. ${ }^{6}$ Isso pode ser verificado com o aumento das importações pouco antes e logo após a chegada da família real ao Brasil, em $1808 .{ }^{7}$ E por isso, quando chegamos ao Brasil, no século XIX, a moda já começava a ser conhecida dos moços e das moças da elite da Corte no Rio de Janeiro. ${ }^{8}$

Em A pata da gazela, José de Alencar descreve Horácio de Almeida, um dândi, um leão ${ }^{9}$ da sociedade carioca. Horácio, antes de se apaixonar, preocupava-se unicamente em se vestir bem e apresentar uma boa figura em sociedade; visitava, inclusive, alfaiates da rua do Ouvidor cotidianamente. Alencar identifica seu leão como um "príncipe da moda". O escritor, portanto, já entendia o significado da moda para a sociedade carioca da época.

Vestir-se elegantemente, ou simplesmente, estar à moda, era algo que se aprendia e se ensinava. Para isso, um novo veículo de comunicação, o jornal, cumpria um papel fundamental. Jornais feitos para senhoras e suas filhas, para avós e netas, eram editados na Corte e tinham como mote principal ensinar a boa sociedade a vestir-se e portar-se em

\footnotetext{
${ }^{5}$ MORAES\&SILVA, Antonio. 2. ed. Lisboa: Typographia Lacerdina, 1813, verbete moda. Disponível em: www.ieb.usp.br.

6 O filósofo Gilles Lipovestsky pensou a moda e a sociedade de consumo no mundo contemporâneo em $O$ império do efêmero. A moda e seu destino nas sociedades modernas. (São Paulo: Companhia das Letras, 2009), especialmente no segundo capítulo, "A moda consumada". A antropóloga americana Mary Douglas, ao lado de Baron Isherwood, debruçou-se sobre o mundo do consumo em um clássico, $O$ mundo dos bens. Para uma antropologia do consumo. Rio de Janeiro: UFRJ, 2013, 2. ed.

7 BOURDIEU, A economia das trocas simbólicas. São Paulo: Perspectiva, 2005. p. 269-295. E também ELIAS, Norbert. A sociedade de corte. Rio de Janeiro: Jorge Zahar, 2001.

${ }^{8}$ No Brasil, não poderia deixar de mencionar a pesquisadora Camila Borges que fez um estudo excelente sobre esse tema e esse período: O símbolo indumentário: distinção e prestígio no Rio de Janeiro, 18081821. Rio de Janeiro: Secretaria Municipal de Cultura/Arquivo do Estado do Rio de Janeiro, 2010.

9 ALENCAR, José de. A pata da gazela. São Paulo: Saraiva, 1954. p. 11. O trecho em que o escritor chama seu personagem de "leão" é o seguinte: "Horácio de Almeida, o nosso leão, voltou a casa à hora do costume, quatro da tarde".
} 
sociedade. Reproduziam-se e comentavam-se gravuras francesas; falava-se dos bailes e das reuniões galantes das famílias abastadas; das moças que se vestiam para dançar e casar; das melhores costureiras e dos melhores alfaiates do Rio de Janeiro.

Escritos em primeiro lugar por jornalistas homens, como o redator do Jornal das Modas, de 1839 a 1842, e mais tarde por senhoras, esses jornais podiam representar uma espécie de emancipação feminina de diversas maneiras. Em primeiro lugar, incentivavam as damas a saírem de casa para fazerem compras e encomendas, a andarem pela cidade, frequentarem confeitarias e docerias, a aparecerem em jantares galantes, ampliando o círculo de sociabilidade para além da família patriarcal. Em segundo lugar, as jornalistas mulheres que escreviam folhas semanais, como o Jornal das Senhoras (1852-1855), se no início eram consideradas um escândalo para a sociedade, depois de um tempo apareciam como exemplos de profissões em que as mulheres poderiam atuar legitimamente fora do lar. Foi o caso de Julia Lopes de Almeida, por exemplo.

Em 12 de janeiro de 1839, o semanário carioca Jornal das Modas, que saía aos sábados, deu uma definição de moda que permaneceu atual ao longo do século XIX:

Há certas coisas que desafiam a inteligência para dar uma solução segura e esclarecida: a moda é, sem dúvida, uma delas. De que servem chapéus de certa cor, vestidos deste feitio, casacas à inglesa, à francesa, etc.? É uma pergunta simples, que muitas vezes acode ao espírito, porém, aparece logo uma resposta que desvanece a indiferença e excita o pensamento: o gosto, os desejos; e é a seguinte: "- Ora, se é moda!". Bem disse um escritor que a moda é hoje um dos piores tiranos. ${ }^{10}$ (Grifo do autor)

A cada número do jornal, uma gravura era descrita e comentada pelo editor. E a cada gravura comentada, uma profusão de detalhes ligados ao se vestir bem aparecia em destaque. No mesmo dia da reflexão acima, são comentados os trajes de duas senhoras. "A que está toda vestida em cor-de-rosa tem um chapéu de Escócia tingido, o que na realidade é muito belo". ${ }^{11}$ Os acessórios, como os chapéus, apareciam em destaque nos comentários do editor bem como nas tabelas de importação e eram itens essenciais para se "andar na moda".

\footnotetext{
10 Jornal das Modas. Ano I, v. I, 12/01/1839, p. 2.

11 Jornal das Modas. Ano I, v. I, 12/01/1839, p. 2.
} 


\section{Figura 1}

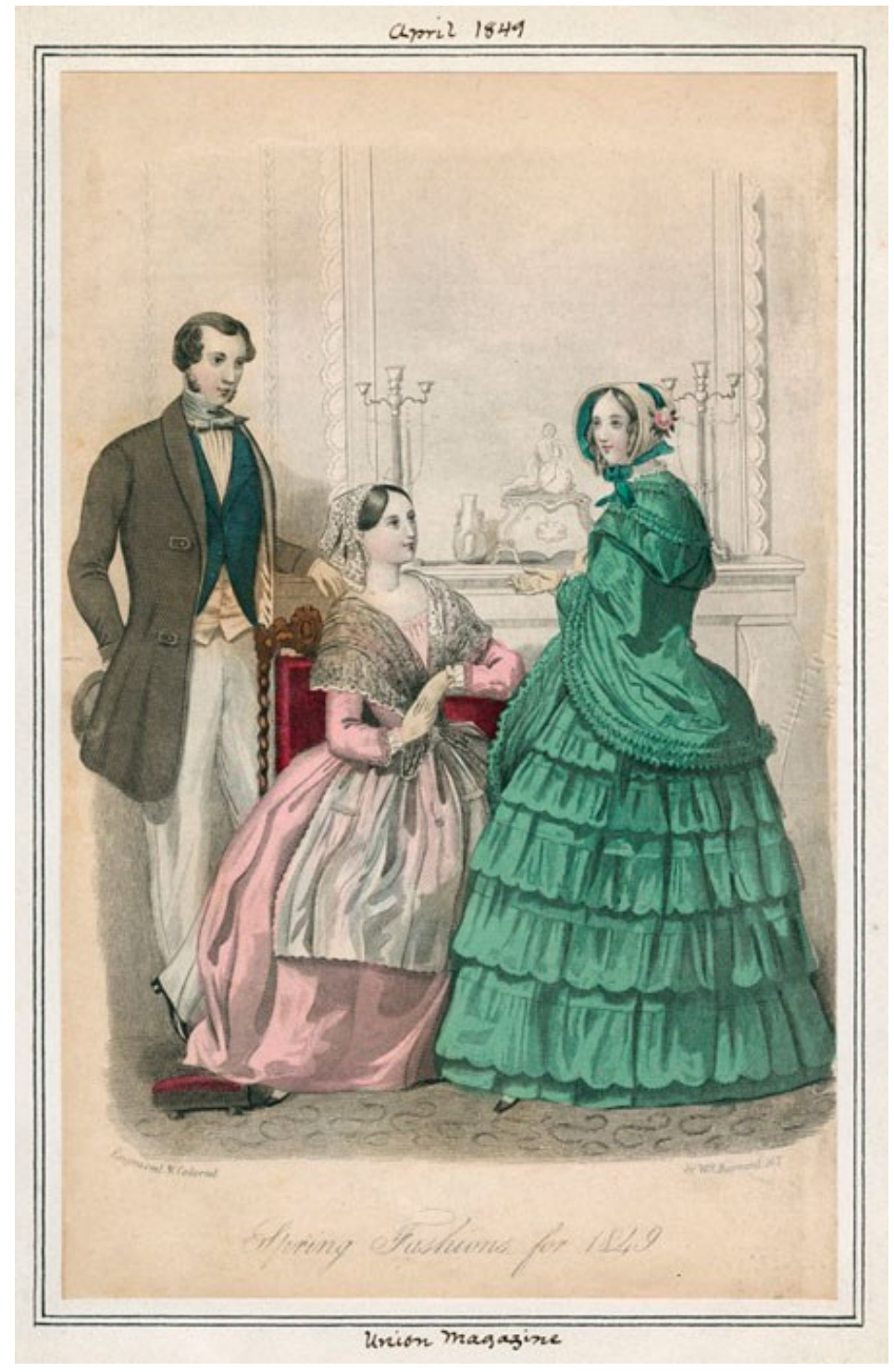

Moda no século XIX.12

Fonte: Jornal das Modas. Ano I, v. I, 12/01/1839, p. 1.

Mas moda era uma palavra nova e passava por múltiplos significados e associações ao longo do século. Moda era uma ideia recente para brasileiros, mas também para os franceses. O poeta francês Charles Baudelaire (1821-1867) associou moda à novidade e à arte. Para ele, a moda passava, necessariamente, pela definição do moderno, de um novo moderno, de um moderno ligado a um novo século. Em um de seus textos sobre arte, intitulado $O$ pintor da vida moderna, arte e moda fundem-se para dar uma ideia de tempo diferente, em que o efêmero predominaria. Num texto que faz parte da mesma série, intitulado $O$ elogio da maquiagem, a moda viria ligada à velocidade, à fotografia, ao instantâneo, ao artifício, à vida na cidade. ${ }^{13}$ Por isso Baudelaire elogia o pintor impressionista Éduard Manet, por sua nova

12 Exemplo de gravura de moda usada no século XIX.

13 O pintor da vida moderna e $O$ elogio da maquiagem são textos jornalísticos de Baudelaire, escritos em 1859 e publicados em 1863 no jornal Le Figaro. Nos textos, Baudelaire explica suas ideias sobre a arte. Para ele, a arte seria o artifício, a fugacidade, o efêmero. A cidade, portanto, seria o lugar do artifício por 
maneira de pintar, ou Félix Tournachon, fotógrafo conhecido como Nadar, devido ao seu novo modo de retratar a sociedade aliada à tecnologia. Moda e cidade, moda e velocidade, moda e arte passam a andar juntas numa ligação que perdura até os dias de hoje. ${ }^{14}$

Até o século XVIII, na França principalmente, a moda estava associada à aristocracia e aos privilégios das corporações de ofício que regulamentavam alfaiates e costureiras. As leis suntuárias eram várias e complexas, além de causarem prisões se desobedecidas.

\begin{abstract}
Assembleias anuais das corporações determinam, após longas deliberações, as mudanças que serão introduzidas na moda. Por mais ponderados que fossem seus decretos, aliás rigorosamente observados, incidiam apenas em questões de detalhe, de modo que a transformação da moda era extremamente lenta. Apenas um acontecimento significativo, como o casamento de um soberano com uma princesa estrangeira, podia resultar em modificações bruscas das formas adotadas no intuito de harmonizá-las aos hábitos ou ao gosto da nova rainha. ${ }^{15}$
\end{abstract}

A moda seria, portanto, antes de mais nada um privilégio da Corte e, como tal, inacessível ao resto da população.

Para Daniel Roche, a moda, esse "mundo encantado de códigos", teria nascido em algum momento em meados do século XVII, quando uma indústria do luxo se estabeleceu em Paris. É dessa indústria que saem as principais criações de moda do século XIX, fato que explica por que Paris tornou-se por muito tempo a capital mundial das novas tendências. ${ }^{16} \mathrm{E}$ é por isso também que, ao longo do século XIX, a França vai se tornar a principal exportadora de roupas pontas para o Brasil. ${ }^{17}$

Foi apenas com a Revolução Industrial que a troca constante de vestimentas por um estrato muito maior da população tornou-se corrente e o termo moda adquiriu uma conotação mais semelhante à que temos hoje. A moda também tinha outra dimensão diferente da social, mais prática e ligada à economia, que percorre o século XIX dando impulso à intensa fabricação de tecidos iniciada em meados do final do século XVIII.

Mais tecidos ingleses significava mais e constantes mudanças no vestuário tanto feminino quanto masculino ao longo do oitocentos. A entrada desses tecidos pelo porto do Rio do Janeiro ditava a moda usada pelas ruas da cidade. Cores, padronagens, tipos de tecido eram importados para depois serem transformados em roupas em ateliês de costura, alfaiatarias ou nas casas, por costureiras ou donas de casa e escravas com habilidades para a costura. Entender essas importações e o que elas significavam em termos de possibilidade de

excelência; lugar efêmero, dos prazeres, da modernidade e da rapidez. Por isso, em as Flores do mal, ele fala das prostitutas, da bebida, dos perfumes, da maquiagem: objetos artificiais.

${ }^{14}$ A ligação entre moda e arte é antiga e, no Brasil, foi reforçada pelo estudo pioneiro de SOUZA, Gilda de Mello e. O espírito das roupas (São Paulo: Companhia das Letras, 1987). Ver também: BENJAMIN, Walter. Obras escolhidas. São Paulo: Brasiliense, 2011, vols. "Magia e técnica", "Rua de mão única" e, principalmente, "Charles Baudelaire, um lírico no auge do capitalismo".

15 GRUMBACH, Didier. Histórias da moda. São Paulo: Cosac \& Naify, 2009. p. 16.

16 ROCHE, Daniel. A cultura das aparências. São Paulo, Senac, 2007. p. 57 a 75. Ver também, do mesmo autor, O povo de Paris. São Paulo: Edusp, 2004, principalmente a segunda parte, "Morar e consumir", p. 143 a 266.

17 GRAHAM, Richard. Grã-Bretanha e o início da modernização no Brasil. 1850-1914. São Paulo: Brasiliense, 1973, apêndice C. 
se transformarem em roupa é essencial para se compreender uma espécie de "economia da moda carioca" do século XIX. As roupas movimentaram o consumo, criaram necessidades que, de certa forma, resultaram na abertura de lojas, de ateliês, de jornais. ${ }^{18}$

\section{Os tecidos importados fazem as roupas na Corte}

Quando os tecidos ingleses começaram a chegar em profusão ao porto do Rio de Janeiro, no início dos anos 1830, a moda pedia saias ligeiramente bufantes, cinturas altas e mangas rente ao corpo, com pequeninos detalhes frisados no punho. Os vestidos tipo império, que causaram furor em Paris logo após a Revolução Francesa, durante o governo de Napoleão Bonaparte, já estavam se transformando.

Aos poucos, de túnicas soltas, inspiradas em vestes gregas da antiguidade, de musselina branca esvoaçante, com decotes profundos, os vestidos se modificavam, adquiriam babados, adornos e volumes ao redor dos pés, como podemos perceber na gravura de Debret reproduzida abaixo. O pintor capturou uma cena de casamento entre negros nesse mesmo período. A noiva estava vestida de branco, mas o vestido império já não era o mesmo da Revolução: tinha babados rente aos pés e cores e rendas fortes no corpete. As damas também se vestiam de maneira semelhante, com mangas curtas já um pouco bufantes, presas rente ao braço.

\section{Figura 2}

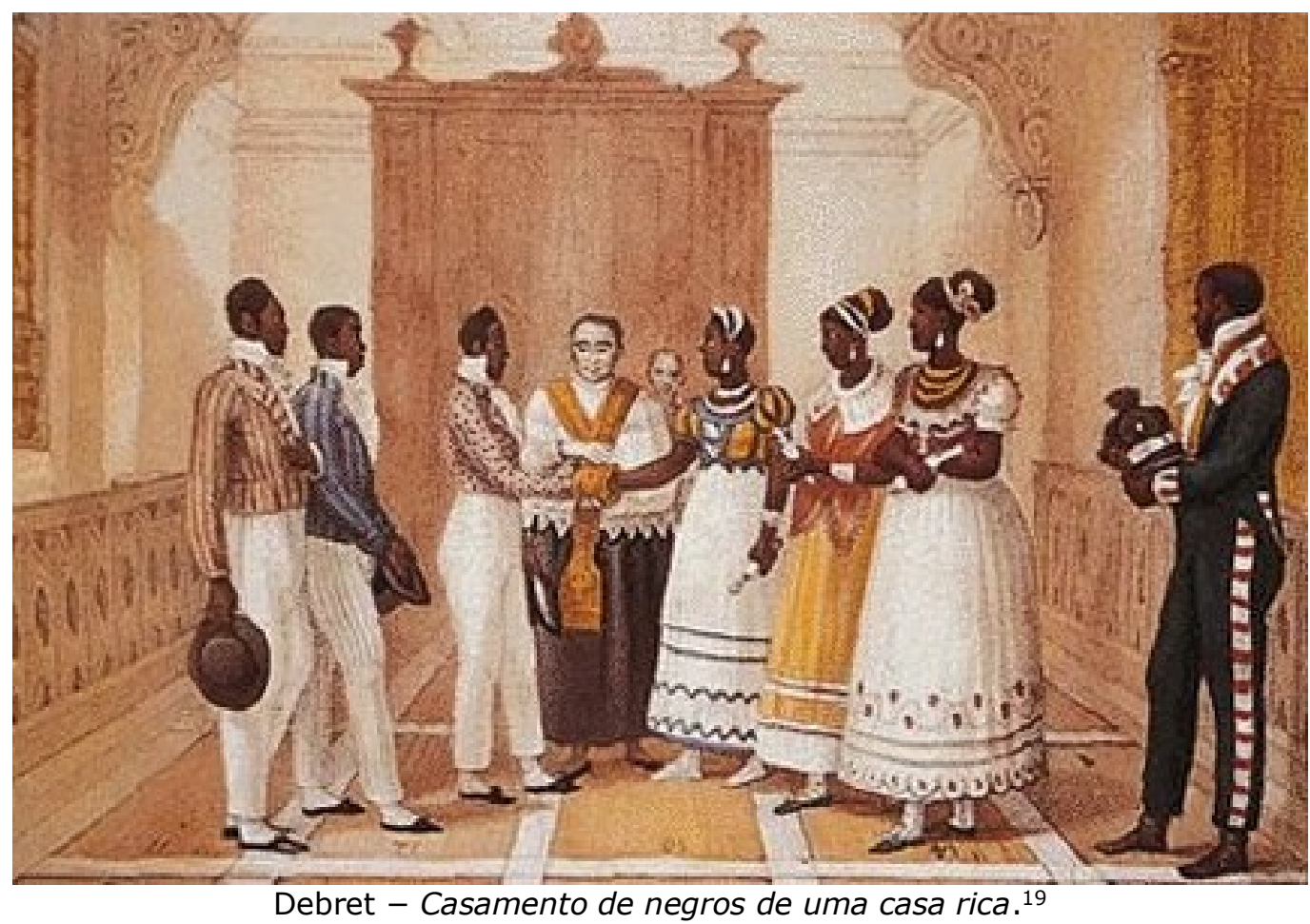

Fonte: BANDEIRA, Julio e LAGO, Pedro Correa do. Debret e o Brasil. Obra completa. Rio de Janeiro: Capivara, 2008. p. 163.

\footnotetext{
18 A leitura do livro de Mary Douglas norteou a confecção deste artigo de várias e diferentes maneiras. DOUGLAS, Mary e ISHERWOOD, Baron. O mundo dos bens. Rio de Janeiro: Editora da UFRJ, 2014.

19 Atenção aos detalhes como os sapatos dos escravos, que não podiam usar esse tipo acessório.
} 
Figura 3

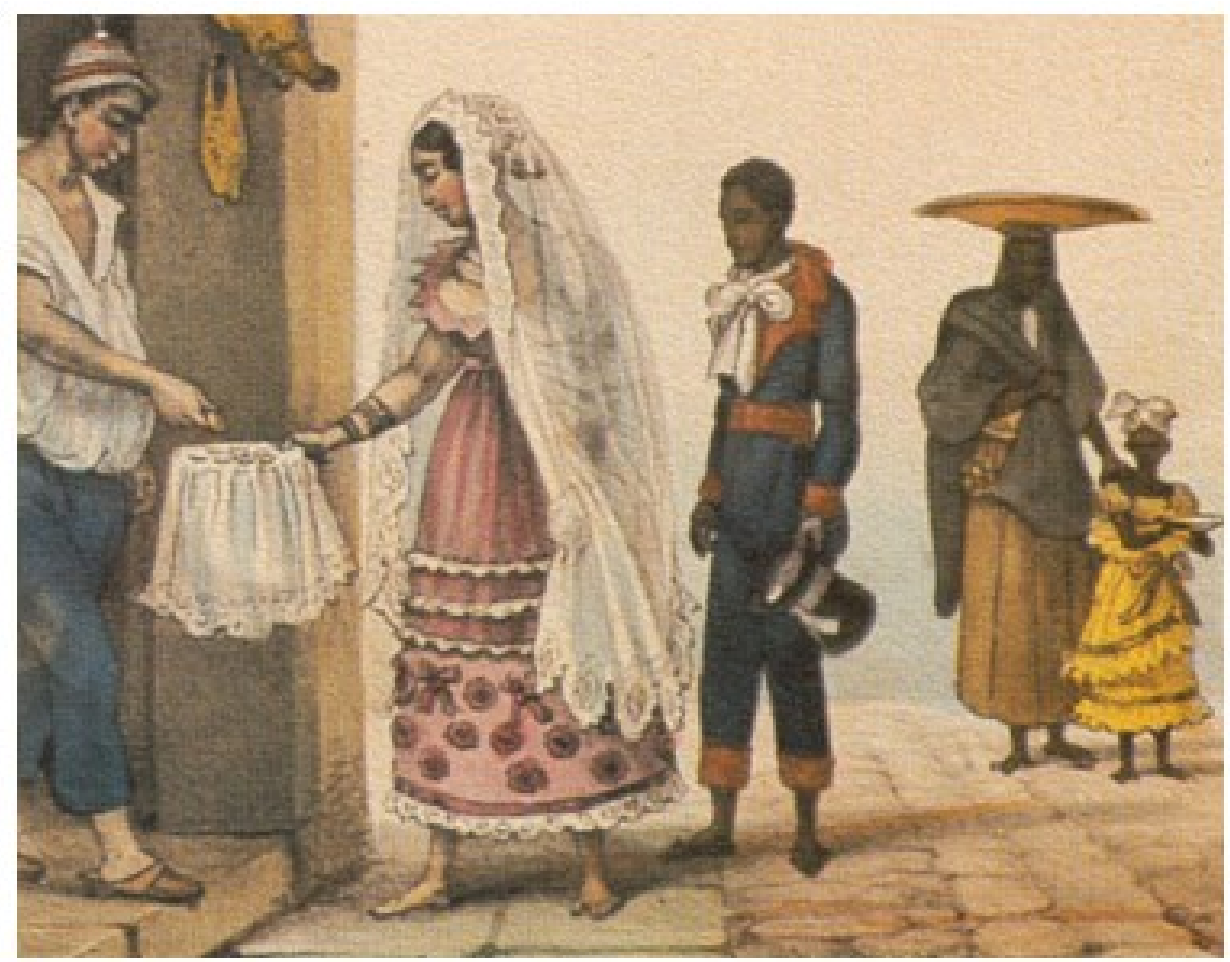

Debret - Voto de uma missa pedida como esmola. ${ }^{20}$

Fonte: BANDEIRA, Julio e LAGO, Pedro Correa do. Debret e o Brasil. Obra completa. Rio de Janeiro: Capivara, 2008. p. 160.

No Rio de Janeiro, nas primeiras décadas do século XIX, as mulheres escondiam-se atrás de mantilhas à oriental e mostravam-se pouco na rua. As exceções eram eventos religiosos, como missas, procissões ou promessas, como vemos na gravura de Debret, a mulher vestida com uma mantilha branca rendada e um vestido império cor-de-rosa, decotado e curto. O cronista Luís Edmundo enxergou na cidade, antes da chegada da família real portuguesa, o atraso de uma cidadela ou de uma aldeia perdida no mundo, com hábitos estranhos, ruas mal calçadas, casarões caindo aos pedaços. "A cidade, na alvorada do século XIX, é o que tinha sido duzentos anos atrás: uma estrumeira." ${ }^{21}$

Com a chegada da família real, em 1808, aportou no Rio, para a maioria dos cronistas e viajantes, a civilização europeia. ${ }^{22}$ Quando desembarcaram, as nobres lisboetas, em seus vestidos império, foram olhadas com admiração e espanto pelas cariocas locais, relatam diferentes cronistas. Dois estrangeiros, Daniel Parrisch Kidder e James Cooley Fletcher, como tantos outros observaram que:

Com a chegada do príncipe-regente, abriram-se os portos. [...] Introduziram-se as modas europeias. Da reclusão e restrições do isolamento, o povo emergiu nas cerimônias festivas da Corte, cujas

\footnotetext{
20 Dama de classe, em 1826, usando vestido cor-de-rosa e uma mantilha de renda.

${ }^{21}$ EDMUNDO, Luís. O Rio de Janeiro do meu tempo. Rio de Janeiro: Imprensa Oficial, 1938, v. 1, p. 19.

22 Sobre a abertura dos portos, ver: ARRUDA, José Jobson de. Uma colônia entre dois impérios: a abertura dos portos brasileiros (1800-1808). Bauru: Edusc, 2008. Ver também: PIMENTA, João Paulo Garrido e SLEMIAN, Andrea. A corte e o mundo. Uma história do ano em que a família real portuguesa chegou ao Brasil. São Paulo: Alameda Casa Editorial, 2008. Ainda sobre o mesmo assunto, é essencial ver: RICUPERO, Rubens e OLIVEIRA, Luís Valente. A abertura dos portos (São Paulo: Senac, 2008).
} 
"A tirania da moda": roupas, comércio e consumo no Rio de Janeiro do século XIX

recepções e festas de gala atraíam multidões de toda a parte. Na sociedade misturada que a capital então ostentava, espanou-se o pó do retraimento, desapareceram antiquados costumes, novas idéias e formas de viver foram adotadas, propagando-se de círculo em círculo e de cidade em cidade. ${ }^{23}$

Dessa forma, quando Maria Graham descreve a corte, em meados da década de 1820, ela também fala de uma espécie de simplicidade elegante, na qual as damas usavam "sedas lisas, musselinas e cambraias", ainda que bastante decotadas. ${ }^{24}$ Sua presença causou comoção e as cariocas não tardaram a imitar-Ihe um hábito europeu, o de usar um chapéu, descartando o uso da mantilha. ${ }^{25} \mathrm{Diz}$ a inglesa que ao fim de uma semana, o inusitado objeto que portava na cabeça foi "copiado em cinquenta cores diferentes". ${ }^{26}$

A moda que chegava aos portos cariocas no século XIX vinha, sobretudo, em forma de tecidos e não de roupas prontas, ainda que chegasse uma imensa variedade de acessórios pelos paquetes ordinários. O historiador Richard Graham, em Grã-Bretanha e o início da modernização do Brasil, ${ }^{27}$ elencou o número das exportações inglesas de tecidos entre 1850 e 1909. Entre 1850-1854, vieram da Inglaterra 8.689.288 libras de tecidos de algodão; 1.859.432 libras de lãs; 1.024 .063 de linhos; 112.947 libras de sedas, totalizando o montante de 11.685 .730 libras ou cerca de $72,55 \%$ do total de todos os produtos exportados para o Brasil - o que incluía produtos alimentícios, produtos de borracha, de barro, joias, prata, armas, drogas e remédios, couro, maquinaria, carvão de pedra, produtos químicos, equipamentos ferroviários, entre outros. As roupas prontas, dentro desse universo de coisas que chegaram aos portos brasileiros, representavam apenas 1,45\% do total das exportações inglesas no período. E, mesmo no final do Império, entre 1885 e 1889, a percentagem de roupas prontas vindas da Inglaterra permaneceu na casa dos 1,29\% das exportações inglesas para o Brasil.

Por isso, quando chegavam, vestidos prontos do estrangeiro eram notícia importante nos jornais que cobriam a moda e as lojas cariocas; e o mesmo ocorria com os cortes de fazendas das mais variadas cores.

O armazém de Wallerstein e Masset recebeu pelo último paquete estes fascinadores vestidos de escomilha bordados de palha, também os de acrophone, gaze, e os de cassa de seda, que efetivamente são uma grande novidade. É preciso vê-los, assim como toda a variedade de primorosas fazendas que lhes chegarão, para admirar a perfeição do trabalho e o apurado capricho desses artefactos franceses. [...]

Os cortes de seda - Médicis, Dubarry, Albanie, Pomone, Esmeralda, Bosphore, Pérolas do Brasil, Montpensier, Val d’or, são inimitáveis e lindíssimos. [...]

\footnotetext{
23 KIDDER, Daniel Parrisch e FLETCHER, James Cooley. O Brasil e os brasileiros. São Paulo: Nacional, 1941. p. 70.

${ }^{24}$ GRAHAM. Maria. Diário de uma viagem ao Brasil e de uma estada nesse país durante parte dos anos de 1821, 1822, 1823. [Trad.]. São Paulo: Companhia Editora Nacional, 1956. p. 117.

25 EDMUNDO, Luís. Recordações do Rio Antigo. Rio de Janeiro: Biblioteca do Exército, 1950. p. 19.

${ }^{26}$ Idem, p. 132.

27 GRAHAM, Richard. Grã-Bretanha e o início da modernização no Brasil. 1850-1914. [Trad.]. São Paulo: Brasiliense, 1973, apêndice C.
} 
As guarnições que receberão de joias de esmalte, trabalhado sobre aço, são o primor da arte: as pulseiras, os alfinetes, e as correntes de relógio encerrarão uma galanteria e delicadeza de trabalho a toda prova! $[\ldots] .^{28}$

O artigo era assinado por Christina, uma jornalista carioca, que tinha uma coluna semanal de comentários sobre a moda. Seu texto nos dá pistas importantes de como se vestir com elegância na época. Como se pode ver no texto acima, os tecidos mais valorizados eram franceses, coloridos e de seda, para as toilettes de grande baile. Rendas, luvas, veludos, tiaras, joias de esmalte eram os complementos ideais. E se os tecidos fossem comprados no armazém do Wallerstein, melhor - sinal de distinção da dama. ${ }^{29}$

Entretanto, se os tecidos franceses eram mais valorizados, as mercadorias inglesas de algodão eram mais numerosas, indicando a profusão desses tecidos entre a população, provavelmente usados para roupas do cotidiano e de diferentes classes sociais.

Tabela de exportações de tecidos e vestuário $(1850-1889)^{30}$

\begin{tabular}{|l|l|l|l|l|l|l|l|l|}
\hline $\begin{array}{l}\text { Ano/ } \\
\text { mercadoria }\end{array}$ & $\begin{array}{l}\mathbf{1 8 5 0 -} \\
\mathbf{8 8 5 4}\end{array}$ & $\begin{array}{l}\mathbf{1 8 5 5 -} \\
\mathbf{1 8 5 9}\end{array}$ & $\begin{array}{l}\mathbf{1 8 6 0 -} \\
\mathbf{1 8 6 4}\end{array}$ & $\begin{array}{l}\mathbf{1 8 6 5 -} \\
\mathbf{1 8 6 9}\end{array}$ & $\begin{array}{l}\mathbf{1 8 7 0 -} \\
\mathbf{1 8 7 4}\end{array}$ & $\begin{array}{l}\mathbf{1 8 7 5 -} \\
\mathbf{1 8 7 9}\end{array}$ & $\begin{array}{l}\mathbf{1 8 8 0 -} \\
\mathbf{1 8 8 4}\end{array}$ & $\begin{array}{l}\mathbf{1 8 8 5 -} \\
\mathbf{1 8 8 9}\end{array}$ \\
\hline $\begin{array}{l}\text { Tecidos de } \\
\text { algodão }\end{array}$ & 8.689 .288 & 10.305 .183 & 12.886 .034 & 17.010 .971 & 15.624 .589 & 14.739 .775 & 15.751 .779 & $\begin{array}{l}13.970 .172 \\
\text { Libras }\end{array}$ \\
\hline Lã & 1.859 .432 & 2.053 .246 & 1.418 .931 & 2.563 .818 & 2.210 .090 & 2.082 .015 & 1.578 .747 & 1.571 .894 \\
\hline Linhos & 1.024 .063 & 1.246 .526 & 1.203 .832 & 1.970 .607 & 1259.871 & 842.980 & 617.608 & 493.984 \\
\hline Sedas & 112.947 & 178.450 & 102.014 & 67.789 & 181.263 & 74.832 & 46.844 & $---\cdot---$ \\
\hline Vestuário & 234.409 & 300.083 & 324.490 & 594.287 & 499.959 & 334.837 & 417.197 & 383.327 \\
\hline
\end{tabular}

Como vimos, ao longo do século XIX, a moda passava pela comercialização dos tecidos, muito mais do que pela produção em escala industrial de roupas, que era feita em casa ou em modistas e alfaiates. Ao longo do século, ocorreu uma passagem sutil, mas irreversível, em direção à industrialização das roupas, que começou com a abertura de ateliês de costura, comandados por costureiras especialistas e alfaiates. Por fim, grandes lojas de varejo ou grandes ateliês passaram a vender roupas prontas ou semiprontas feitas por pequenas costureiras.

Esse movimento de transformação de tecidos em roupas prontas, de certa maneira, começou em Paris, nas primeiras décadas do século XIX. O escritor Émile Zola, em seu romance $O$ paraíso das damas, descreveu um mundo comercial que girava em torno da compra e venda de tecidos. O protagonista do livro não era uma personagem, mas uma loja, um magazine - e uma nova maneira de vender. A fachada da grande loja, que dava para a praça Gaillon e continuava ao longo da rue Michodière e da rue Neuve Saint-Augustin,

28 Jornal das Senhoras, 2/05/1852, p. 19.

${ }^{29}$ As assinaturas do Jornal das Senhoras podiam ser feitas no próprio armazém de Wallerstein, que ficava na rua do Ouvidor, 70 ou nas lojas de Desmarais, rua do Ouvidor, 86 e Mongis, rua do Ouvidor, 87. Também se podia assinar o semanário na gráfica que o imprimia, a Typographia de Santos e Silva Junior, na rua da Carioca, 32.

30 GRAHAM, Richard. Grã-Bretanha e o início da modernização no Brasil. 1850-1914. [Trad.]. São Paulo: Brasiliense, 1973, apêndice C. 
impressionava os passantes. Nas vitrines, composições delicadas dos mais diversos tecidos e das mais diferentes cores, despencavam em cascatas. Na primeira cena, Denise, a pobre moça do interior, que chega a Paris com os irmãos, via, admirada, o poder daquela loja:

\begin{abstract}
Enquadrando a soleira da porta, pendiam, em faixas estreitas, tiras de peles para adornar vestidos: o cinza fino das costas dos esquilos, a neve pura do ventre dos cisnes, os pelos de coelho, do falso arminho, e da falsa marta. Além disso, em estojos dispostos em mesa à entrada, junto de uma pilha de cortes avulsos, acumulavam-se acessórios anunciados por um nada: luvas e xales de lã tricotados, toucas, coletes, todo um mostruário de inverno em cores vivas, tricotadas, estampadas, matizadas, listradas ou salpicadas de um vermelho sangrento. [...] Era uma exposição gigante de feira livre, a loja parecia estar explodindo e lançando todo o excesso para a rua. ${ }^{31}$
\end{abstract}

Ao longo do romance, Denise vai tornar-se vendedora e conhecer todos os segredos de uma nova modalidade de venda capitalista, uma loja que não media esforços para seduzir as mulheres com uma infinidade de produtos, dispostos com os variados preços. Luvas, chapéus, mantôs, roupinhas para crianças, lenços e bengalas para homens - tudo se achava na loja. A cada liquidação semestral, o magazine apostava todas as suas fichas. E, a cada liquidação, a loja se tornava mais forte e mais rica. Tanto Denise aprende a se comportar nesse mundo capitalista que, ao longo dos anos, galga posições de prestígio rapidamente dentro da loja até assumir a posição de gerente de vendas da seção feminina. Nos anos em que estava lutando para aprender a vender, a seção de Denise foi a que mais mudou na loja - de tecidos e acessórios, passou a vender também roupas semiprontas, ajustadas de acordo com o corpo de cada cliente. ${ }^{32}$

Desde o século XVIII, os tecidos, assim como aconteceria com as roupas um século mais tarde, eram regulados pelas estações do ano. No verão europeu, estampas pequenas, com flores miúdas, tons pastel; no inverno, veludos e lãs, em tons de cinza, preto, azul, bordô. Um dos grandes costureiros ingleses do período, Charles Frederick Worth, resumiu, no trecho citado abaixo, o que deveria ser usado por cada mulher nos tempos de Luís XIV. ${ }^{33}$ As proibições e os deveres no uso dos tecidos pelas mulheres ainda estavam ligados às diferentes leis suntuárias do século XVIII, mas a permanência do que deveria ou não ser usado foi impressionante e perdurou ao longo do século XIX, mesmo quando os vestidos prontos já dominavam a moda.

\footnotetext{
31 ZOLA, Émile. O paraíso das damas. São Paulo: Estação Liberdade, 2007. p. 33.

32 ZOLA, Émile. O paraíso das damas. São Paulo: Estação Liberdade, 2007.

33 Sobre Charles Frederick Worth, ver: GRUMBACH, Didier. Histórias da moda (São Paulo Cosac \& Naify, 2009. p. 17-24). No Brasil, temos o estudo aprofundado de: DEBOM, Paulo. Sob o império das aparências: moda e imagem na França de Luís Bonaparte (1848-1870). Tese de Doutorado. Universidade do Estado do Rio de Janeiro, Rio de Janeiro, 2015.
} 
Os tecidos eram classificados segundo as estações: para o inverno, veludos, cetins, ratinas, ${ }^{34}$ percais; ${ }^{35}$ para o verão, tafetás; ${ }^{36}$ para o outono e a primavera, os percais leves. Até as rendas variavam de acordo com as estações. O ponto inglês, embora não fosse mais quente que as malinas, ${ }^{37}$ já não podia aparecer antes das festas de Longchamp. As peles eram usadas a partir do dia de Todos os Santos; na Páscoa, abandonavam-se os regalos, sendo proibido retomá-los mesmo que nevasse. Assim que uma mulher chegava aos 40 anos, já não podia se apresentar na Corte sem um coque coberto por uma renda preta. ${ }^{38}$

No Brasil, as modas seguiam o que se usava em Paris ou na Inglaterra. E, na Inglaterra ou em Paris, o hábito de mudar de tecido e, consequentemente, de roupas, conforme a estação do ano, começou primeiramente com as mudanças de tecidos. Esse foi o padrão que ficou estabelecido para lojas, costureiras e alfaiates desde o fim do século XVIII. As mudanças sazonais da moda, mangas maiores ou menores, estampas, babados, foram apenas um passo que pareceu perfeitamente natural, dadas as mudanças que já vinham ocorrendo com os tecidos. Os armazéns e as lojas de fazendas anunciavam a grande variedade de tecidos, para todas as estações, como podemos ver abaixo, num anúncio de 1861 , publicado no Almanaque Laemmert. $^{39}$

34 Ratina: tecido felpudo de lã. Em francês, "ratine". Ver "Dicionário de tecidos antigos" em: MONTELEONE, Joana. O circuito das roupas: a corte, o consumo e a moda. Rio de Janeiro, 1940-1899. Tese de Doutorado. Universidade de São Paulo, São Paulo, 2013, anexo 1.

35 Percal: tecido hoje usado em roupas de cama, extremamente macio, feito com fio penteado de algodão. Ver "Dicionário de tecidos antigos" em: MONTELEONE, Joana. O circuito das roupas: a corte, o consumo e a moda. Rio de Janeiro, 1940-1899. Tese de Doutorado. Universidade de São Paulo, São Paulo, 2013, anexo 1.

36 Tafetá é um tecido brilhante e nobre fabricado com fios de seda. É aplicado na confecção de roupas mais finas e no revestimento de acessórios femininos.

37 Malina é uma renda trabalhada, muito fina, feita na Bélgica.

38 WORTH, Gaston. La couture et la confection dês vêtements de femmes. Paris: Chaix, 1895. Gaston era neto de Charles Frederick Worth, grande costureiro do período. 1861. 
Figura 4

8

MOTABILIDADES,

\section{LOJA DE FAZENDAS FINAS \\ 20} PARA BOMENS B SEIHORAS

\section{ANTONIO JOAQUTM DE MAGALHĀES} By RUA Da QUITANDa

isacisa on do zospicio

Este grande e bem conhecido estabelecimento tem sempre completo sortimento de fazendas para homens e senhoras, como sejũo: restidlos, manteletes, capas, meias, lencos, camisinhas, basquincs, leques, pentes, bordados para senhuras, etc., c tom especialidade vestidos de. seda para passeio, bailes e casamentos, e tudo o que diz respeito a sedas; e bem assim casimiras, pannos, brins, chapius, gravatas, camisas, ceroulas, bengalas e meias para homens, e muitos outros artigos pertencentes ao seu negocio, tudo por preços muito razoavcis. Recommenda-se por isso este estabclecimento ao respeitavel publico.

\section{LOUZADA \& C.}

ESTABELECIDOS HA NOVE ANNOS NA

Rua da Alfandega N. 141

Continuão sempre a ter no seu armazem N. 141 um grande e variado sortimento

DE FAZENDAS DE TODAS AS QUALIDADES

as quaes só comprão a dinheiro e vendem por alacado e a varejo pelos preços mais razoaveis que é possivel encontrar-se.

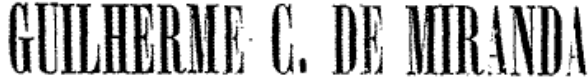

\section{RUA DO OUVIDOB 1336}

Armazem de fazendas finas e modas que $\mathrm{rem}$ cebe directamente de Paris por todos os paquem tes mensaes.

Anúncio de fazendas.

Fonte: Almanaque Laemmert, 1861.

O historiador brasileiro Wanderley Pinho indicou a década de 1860 como aquela em que as brasileiras começaram a vestir os figurinos de acordo com a estação daqui, dos trópicos, e não seguir à risca o que se usava na Europa, numa total inversão de estações. Mas, mesmo na Europa, a ideia de ter estações para roupas era recente e estava se difundindo aos poucos. ${ }^{40}$

40 GRUMBACH, Didier. Histórias da moda. São Paulo: Cosac e Naify, 2009. p. 15-19. 
"A tirania da moda": roupas, comércio e consumo no Rio de Janeiro do século XIX

"Cerca de 1860", diz Pinho, "é que começam a respeitar-se as estações, desobedecendo um pouco a anterior imitação absoluta". ${ }^{41}$

Nos volumes do Estatística do comércio marítimo do Brasil, ${ }^{42}$ pode-se constatar os diferentes tipos de tecidos que chegam ao país no período: algodão, lã, linho e seda; e os principais países exportadores, parceiros comerciais importantes do Brasil no período: GrãBretanha, Alemanha, França, Estados Unidos, Itália, Portugal, Argentina e Paraguai.

Pelas estatísticas do comércio marítimo, podemos perceber o movimento do capitalismo mundial. Chegavam ao Rio de Janeiro, dentro de todo o rol de mercadorias elencadas, principalmente tecidos, vindos da Grã-Bretanha em plena Revolução Industrial. De todos os tecidos importados, o algodão era de longe o mais utilizado no cotidiano, em diferentes formas. Do algodão em fio simples e trapos importou-se, em 1870-1873, 61.765 quilos que valiam 59:469\$000 contos de réis. Nenhum outro país conseguiu que seu algodão chegasse nem perto desses algodões ingleses; o segundo colocado foi a Alemanha, com 2.606 quilos a um valor de 1:815\$000 contos de réis. ${ }^{43}$

A Grã-Bretanha aparece em primeiro lugar em quase todas as tabelas de importação de tecidos. Dessa maneira, vieram para o Rio de Janeiro em 1870-71, 255.057 quilos de algodão em caroço ou em rama, o equivalente a 532:199\$000 contos de réis, o que nos dá uma pista de que, provavelmente, esse algodão foi processado por aqui mesmo. Ainda no item algodão, vieram 6.280.111 quilos ou 9.336:325\$000 contos de réis de panos de algodão cru, curado e lavrado, principal item para a confecção de roupas dos mais variados tipos. ${ }^{44}$

\footnotetext{
41 PINHO, Wanderley. Salões e damas do segundo império. São Paulo: Livraria Martins Editora, 1970.

42 Mapa geral das mercadorias importadas e despachadas para consumo (anos entre 1841-1891). Rio de Janeiro, Typografia Nacional, 1878. Disponível em: http://memoria.nemesis.org.br/. Acesso em: 2011. 0 site passou por alterações recentes.

43 Mapa geral das mercadorias importadas e despachadas para consumo anos de 1871-1872, p. 171 e seguintes. Disponível em: <http://memoria.nemesis.org.br/>. Acesso em: 20/08/2010.

44 Mapa geral das mercadorias importadas e despachadas para consumo anos de 1871-1872, p. 171 e seguintes. Disponível em: <http://memoria.nemesis.org.br/>. Acesso em 20/08/2010).
} 


\begin{tabular}{|l|l|l|}
\hline \multicolumn{4}{|l|}{ Tecido $^{\mathbf{4 5}}$} \\
\hline Algodão em caroço, rama, etc. \\
\hline País & Quant. (Kg) & Valor \\
\hline Alemanha & 4.496 & $8: 844 \$ 000$ \\
\hline Bélgica & 411 & $822 \$ 000$ \\
\hline Confed. Argentina & 947 & $1: 894 \$ 000$ \\
\hline Estados Orientais & 800 & $1: 000 \$ 000$ \\
\hline Estados Unidos & 40 & $81 \$ 000$ \\
\hline França & 20.954 & $40: 451 \$ 000$ \\
\hline Grã-Bretanha & 255.057 & $532: 199 \$ 000$ \\
\hline Portugal & 2.941 & $5: 744 \$ 000$ \\
\hline Países indeterminados & 2548 & $5: 060 \$ 000$ \\
\hline Total & 288.194 & \\
\hline
\end{tabular}

Vieram para o país alguns itens de decoração feitos com algodão, como tapetes, oleados e alcatifas. A quantidade total era de 123.363 quilos, oriundos principalmente da GrãBretanha. Esses mesmos itens de decoração aparecem com diferentes tipos de fios, como algodão, linho e lã. A maior quantidade vinda para o Brasil era de linho, 48.636 quilos, importados majoritariamente da Grã-Bretanha (mais de 40 mil quilos). A quantidade de tapetes de lã é de 39.778 quilos, com a maioria da produção também vinda da Grã-Bretanha, mais de 33 mil quilos. Os tapetes e similares de algodão somaram 34.948 quilos.

\begin{tabular}{|l|l|l|}
\hline \multicolumn{3}{|l|}{ Tecido } \\
\hline Alcatifas, tapetes e oleados de algodão \\
\hline País & Quant. $(\mathrm{Kg})$ & Valor \\
\hline Alemanha & 8.806 & $12: 918 \$ 000$ \\
\hline Bélgica & 4.798 & $7: 987 \$ 000$ \\
\hline Estados Orientais & 180 & $285 \$ 000$ \\
\hline Estados Unidos & 755 & $881 \$ 000$ \\
\hline França & 6.869 & $8: 222 \$ 000$ \\
\hline Grã-Bretanha & 13.540 & $18: 038 \$ 000$ \\
\hline Total & 34.948 & \\
\hline
\end{tabular}

45 Optei por transcrever a tabela tal qual ela foi editada por não querer adulterar um documento de época. Aqui, portanto, elas foram apenas transcritas, notando que o site passou por alterações recentes. Algumas vezes a soma não bate, nem as quantidades são especificadas. A grafia também pode ser diferente. 


\begin{tabular}{|l|l|l|}
\hline \multicolumn{3}{|l|}{ Tecido } \\
\hline \multicolumn{3}{|l|}{ Alcatifas, tapetes e oleados de linho } \\
\hline País & $\begin{array}{l}\text { Quant. } \\
(\mathrm{Kg})\end{array}$ & Valor \\
\hline Alemanha & 730 & $817 \$ 000$ \\
\hline Bélgica & 242 & $161 \$ 000$ \\
\hline Estados Orientais & 50 & $83 \$ 000$ \\
\hline Estados Unidos & 435 & $415 \$ 000$ \\
\hline França & 2.744 & $2: 671 \$ 000$ \\
\hline Grã-Bretanha & 44.435 & $31: 804 \$ 000$ \\
\hline Total & 48.636 & \\
\hline
\end{tabular}

\begin{tabular}{|l|l|l|}
\hline \multicolumn{3}{|l|}{ Tecido } \\
\hline Alcatifas, tapetes e oleados de lã \\
\hline País & $\begin{array}{l}\text { Quant. } \\
(\mathrm{Kg})\end{array}$ & Valor \\
\hline Alemanha & 1.006 & $2.815 \$ 000$ \\
\hline Bélgica & 840 & $2: 658 \$ 000$ \\
\hline Confed. Argentina & 130 & $520 \$ 000$ \\
\hline Estados Orientais & 291 & $904 \$ 000$ \\
\hline França & 2.889 & $11: 238 \$ 000$ \\
\hline Grã-Bretanha & 33.997 & $112: 210 \$ 000$ \\
\hline Portugal & 122 & $488 \$ 000$ \\
\hline Países indeterminados & 503 & $5: 476 \$ 000$ \\
\hline Total & 39.778 & \\
\hline
\end{tabular}

Ao longo de todo o século XIX, tanto a musselina como suas irmãs, a cassa, o filó ou o barége, reinaram como os tecidos mais utilizados tanto na produção de roupas quanto em outros itens de decoração. Todos são uma espécie de tecido de algodão muito fino e transparente. ${ }^{46}$ Podiam ser usados como cortinas ou mosquiteiros, como vemos na descrição de Theodor von Leithold e Ludwig von Rango, que estiveram no Rio, em 1819: "Contra esses insetos usam-se mosquiteiros, cortinas de musselina verde ou de gaze, em que eles conseguem às vezes penetrar por algum buraco, tornando-se, então, nesse recinto fechado ainda mais irritantes [...]". ${ }^{47}$ Mas também eram muito usados como parte de "roupas de baixo", adornos para espartilhos, corpetes, roupões, saias e saiotes. Algumas vezes, esse tipo de roupa podia ser usado como uma vestimenta informal, dentro de casa, em que visitas mais íntimas podiam ser recebidas para um chá. Machado de Assis descreveu uma roupa desse modelo em $A$ mão e a luva:

46 Ver "Pequeno dicionário de tecidos antigos" no "Dicionário de tecidos antigos" em: MONTELEONE, Joana. O circuito das roupas: a corte, o consumo e a moda. Rio de Janeiro, 1940-1899, anexo 1.

47 LEITHOLD, Theodor von e RANGO, Ludwig von. O Rio de Janeiro visto por dois prussianos em 1819. [Trad.]. São Paulo, Companha Editora Nacional, 1966. p. 39. 
O roupão - de musselina branca - finamente bordado, não deixava ver toda a graça do talhe [...]. Todo o colo ia coberto até o pescoço onde o roupão era preso por um pequeno broche de safira. Um botão, do mesmo mineral, fechava em cada pulso as mangas estreitas e lisas, que rematavam em folhos de renda. ${ }^{48}$

Nas tabelas de importação, o barége, a musselina, a cassa e o filó aparecem com valores significativos, ainda que a quantidade de quilos não seja especificada, talvez por serem tecidos muito finos. A Grã-Bretanha aparece novamente em primeiro lugar, com quase 2,9 mil contos de réis. Para termos uma ideia de quanto isso representava no cotidiano do século XIX, podemos ver o exemplo de quanto custava um carro completo e novo, espécie de carruagem com seis cavalos, em 1876: cerca de 1:800\$000.49 Assim, a quantidade de musselina e equivalentes que chegou ao Rio de Janeiro, no período, podia comprar 1.609 carros; ou podemos também fazer outra comparação e ver o quanto isso valia em escravos. Em Areias, interior paulista, um escravo, homem, em 1870, valia 1:846\$000. Dessa forma, o valor de cerca de 80 escravos podia comprar a totalidade de musselina, barége, cassa e filó exportada para o Brasil pela Alemanha no período, ou seja, 148:947\$000. ${ }^{50}$

\begin{tabular}{|l|l|}
\hline \multicolumn{2}{|l|}{ Tecido } \\
\hline Bareges, musselinas, cassas, filós, etc. \\
\hline País & Valor \\
\hline Alemanha & $148: 947 \$ 000$ \\
\hline Bélgica & $33: 025 \$ 000$ \\
\hline Confed. Argentina & $7: 789 \$ 000$ \\
\hline Estados Orientais & $4: 900 \$ 000$ \\
\hline Estados Unidos & $13: 877 \$ 000$ \\
\hline França & $587: 013 \$ 000$ \\
\hline Grã-Bretanha & $2.896: 252 \$ 000$ \\
\hline Itália & $1: 926 \$ 000$ \\
\hline Paraguai & $467 \$ 000$ \\
\hline Portugal & $1: 806 \$ 000$ \\
\hline Países indeterminados & $76: 145 \$ 000$ \\
\hline Total & $4.451: 757 \$ 000$ \\
\hline
\end{tabular}

Chegaram também da Grã-Bretanha itens como 10.390 quilos de belbute, belbutina, bombazina de algodão, valendo 41:580\$000 contos de réis. Belbute e belbutina eram uma

48 ASSIS, Joaquim Maria Machado de. A mão e a luva (1874). São Paulo: Editora Cultrix, 1960. p. 191.

49 Maria Luzia Ferreira de Oliveira recuperou o inventário de Antonio Joaquim da Silva no seu livro. Ver: OLIVEIRA, Maria Luzia Ferreira de. Entre a casa e o armazém. São Paulo: Alameda Casa Editorial, 2005. p. 47.

50 Para um estudo sobre o preço dos escravos, ver: MOTTA, José Flávio. Escravos daqui, dali e de mais além: o tráfico interno de cativos na expansão cafeeira paulista. São Paulo: Alameda Casa Editorial, 2012. p. 189. 
espécie de tecido de algodão aveludado usado em vestidos, camisas, forros de coletes ou roupas de baixo, algumas vezes como um ornamento, outras como tecido para uma roupa completa. ${ }^{51}$

Assim, o belbute apareceu em vários inventários do século XVIII, como no inventário de José Ayres Gomes, inconfidente, em 1791, o que nos dá a ideia de sua riqueza na época. Ele possuía:

Fraque de baetão cor-de-rosa seca forrado de baeta azul. Casaca de chita amarela com sua veste sem mangas, tudo forrado de tafetá verde. Veste de belbute branco, e outra de fustão branco. Calção de pano amarelo, com ligas de galão de ouro. 6 camisas, quatro de bretanha e duas de linho $[\ldots] .{ }^{52}$

Já no começo do século XIX, John Luccock observava, no sul, que os homens usavam um poncho "[...] frequentemente orlado de belbute à volta toda e forrado de baeta de tonalidade alegre; quando de algodão, enfeitam-no com franjas de cores variegadas, entretecidas com a própria peça, e é artigo de manufatura sul-americana". ${ }^{53}$

Já a bombazina ou bombazine como são conhecidos hoje em dia, são uma espécie de tecido de veludo de seda ou algodão com sulcos muito profundos na camada de uso no sentido da teia. É um tipo de tecido bastante resistente, de amplo uso, tanto no vestuário masculino como no feminino e também na decoração da casa. ${ }^{54}$

\begin{tabular}{|l|l|l|}
\hline \multicolumn{3}{|l|}{ Tecido } \\
\hline Bareges, belbutinas, bombasinas do algodão \\
\hline País & Quant. $(\mathrm{Kg})$ & Valor \\
\hline Alemanha & 1.936 & $4: 625 \$ 000$ \\
\hline Estados Orientais & 4.820 & $5: 499 \$ 000$ \\
\hline França & 321 & $918 \$ 000$ \\
\hline Grã-Bretanha & 10.390 & $41: 580 \$ 000$ \\
\hline $\begin{array}{l}\text { Países } \\
\text { indeterminados }\end{array}$ & 1.577 & $3: 345 \$ 000$ \\
\hline Total & 19.044 & \\
\hline
\end{tabular}

\footnotetext{
51 Ver "Pequeno dicionário de tecidos antigos" no "Dicionário de tecidos antigos" em: MONTELEONE, Joana. O circuito das roupas: a corte, o consumo e a moda. Rio de Janeiro, 1940-1899, anexo 1.

52 Autos da Devassa da Inconfidência Mineira (1789-1791). v. V, Rio de Janeiro: Ministério da Educação/Biblioteca Nacional, 1936. p. 481.

53 LOCCOCK, John. Notas sobre o Rio de Janeiro e partes meridionais do Brasil (1808-1818). São Paulo, Belo Horizonte, EDUSP/Itatiaia Editora, 1975. p. 127.

54 Ver "Pequeno dicionário de tecidos antigos" no "Dicionário de tecidos antigos" em: MONTELEONE, Joana. O circuito das roupas: a corte, o consumo e a moda. Rio de Janeiro, 1940-1899, anexo 1.
} 
Foram importados também brim, cassineta, castor e metim da Grã-Bretanha num total de 1.610.607 quilos, que valiam 224:907\$000 contos de réis. O brim, tecido mais pesado, podia ser usado em calças, paletós, aventais ou roupas de trabalho. ${ }^{55}$

Brim era um tecido antigo, conhecido e usado largamente pelo menos desde o começo do século XVIII. O Dicionário Raphael Bluteau dá como definição de brim o seguinte texto: "Pano de linho cru, fabricado em Hamburgo, e os há de duas castas; uns são muito tapados e fortes e servem para velas menores dos navios, como Joanetes, Cutelos e etc. os outros são estreitos, e de várias cores, e servem para forros de vestidos. Vide tomo 2 do vocabulário". ${ }^{56} \mathrm{~A}$ outra definição diz que brim era o mesmo que "lençaria, da qual há muitas castas. Brim ordinário, brim fino, largo, grosso, curado e etc". ${ }^{57}$

A ideia de que o brim era um tecido fabricado primordialmente em Hamburgo, na Alemanha, era corrente no século XIX. Por isso, em 1881, Aluísio Azevedo, em $O$ mulato, descreve um personagem da seguinte maneira: "Viam-se [...] capitalistas [...] por debaixo do chapéu de pelo [...]. Calça de brim de Hamburgo". ${ }^{58}$ Para os brasileiros, especialmente os do Rio de Janeiro, ser de Hamburgo era uma espécie de propaganda de um bom produto, conhecido e fabricado há tempos por uma cidade industrial. Ser capitalista também contava como propaganda, já que a indumentária que os empresários passaram a usar remetiam às cidades industrializadas da Europa.

Cassineta, castor e metim ${ }^{59}$ eram tecidos mais finos - o metim, uma espécie de algodão cardado usado para forros de vestidos; a cassineta, tecido fino e leve, geralmente usado para vestidos, saias e camisas. O castor era usado basicamente em chapéus de várias espécies.

\footnotetext{
55 Ver "Pequeno dicionário de tecidos antigos" no "Dicionário de tecidos antigos" em: MONTELEONE, Joana. O circuito das roupas: a corte, o consumo e a moda. Rio de Janeiro, 1940-1899, anexo 1.

56 Dicionário Rapahel Bluteau. Disponível em: <http://www.ieb.usp.br/catalogo_eletronico/>. Acesso em: $11 / 12 / 2012$.

57 Dicionário Raphael Bluteau. Disponível em: <http://www.ieb.usp.br/catalogo_eletronico/>. Acesso em: $11 / 12 / 2012$.

58 AZEVEDO, Aluísio. O mulato. São Paulo, Martins Editora/Instituto Nacional do Livro/MEC, 1975. p. 34.

59 Ver "Pequeno dicionário de tecidos antigos" no "Dicionário de tecidos antigos" em: MONTELEONE, Joana. O circuito das roupas: a corte, o consumo e a moda. Rio de Janeiro, 1940-1899, anexo 1.
} 
"A tirania da moda": roupas, comércio e consumo no Rio de Janeiro do século XIX

\begin{tabular}{|c|c|c|}
\hline \multicolumn{3}{|l|}{ Tecido } \\
\hline \multicolumn{3}{|c|}{ Brins, cassinetas, castores, metins, etc. } \\
\hline País & Quant. (Kg) & Valor \\
\hline Alemanha & 113.645 & $224: 907 \$ 000$ \\
\hline Bélgica & 73.393 & $153: 186 \$ 000$ \\
\hline China & 181 & $592 \$ 000$ \\
\hline Confed. Argentina & 1.590 & $3: 475 \$ 000$ \\
\hline Estados Orientais & 7.881 & $15: 770 \$ 000$ \\
\hline Estados Unidos & 51.407 & $104: 348 \$ 000$ \\
\hline França & 150.537 & $327: 756 \$ 000$ \\
\hline Grã-Bretanha & 1.200 .109 & $2.476: 599 \$ 000$ \\
\hline Portugal & 1.963 & $3: 946 \$ 000$ \\
\hline Países indeterminados & 9.901 & $39: 472 \$ 000$ \\
\hline Total & 1.610 .607 & \\
\hline
\end{tabular}


Figura 5

FAZENDAS E MODAS

AU LUXEMBOURG

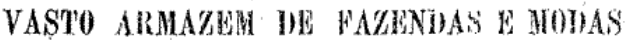

ne.

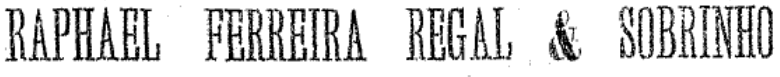

20 Rua da Quitanda: 20

Neste antigo estabolocimento encontra-se simpre varia-

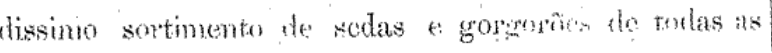

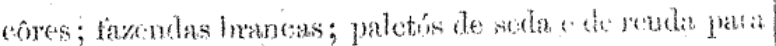

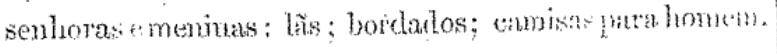

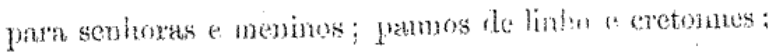

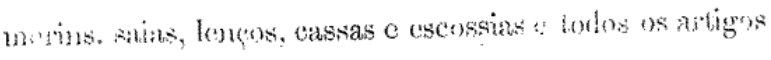

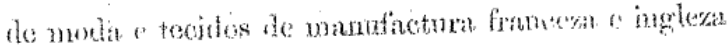

1)speciabialate

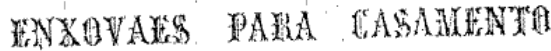

FAZTINAS PANA LUTO

Anúncio. Almanaque Laemmert, $1871 .^{60}$

Na rua da Quitanda, 20, Raphael Ferreira Regal vendia na sua loja Au Luxemburg um

[...] variadissimo (sic) sortimento de sedas e gorgurões de todas as cores, fazendas brancas, paletós de seda e da renda para senhoras e meninas; lãs, bordados, camisas para homens, para senhoras e para meninos, panos de linho e cretones, morins, saias, lenços, cassas e escoceses e todos os artigos de moda e tecidos de manufatura francesa e inglesas. ${ }^{61}$

Não era uma loja na rua no Ouvidor, portanto devia vender produtos mais em conta destacavam-se os itens para o vestuário do cotidiano. Ao lado estava a loja de Norberto José

60 Disponível em: <http://brazil.crl.edu/bsd/bsd/almanak/al1871/00001303.html>. Acesso em: 26/01/2012.

61 Disponível em: <http://brazil.crl.edu/bsd/bsd/almanak/al1871/00001303.html>. Acesso em: 26/01/2012. 
da Silva Coelho, A figura risonha, no número 26, com a miscelânea de artigos característica da primeira metade do século XIX, "miudezas de armarinho, modas, fazendas e ferragens".

\section{Figura 6}

48

NOTABYLIDADES

\section{A RIGERA RIZONHA}

20 RCL DI QUTTAII) 20

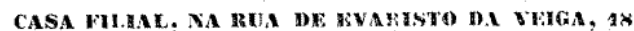

NORBER'IO JOSÉ DA SILVA COELIIO \& $\mathrm{C}$. NEGOCIANTES

DE:

\section{Miudezas de armarinho}

MODAS, FAZENDAS E FERRAGENS,

Cha, rapré, e velas de cera e te composigãa,

IX̀rosene, lampeóes e to ins a pextenchs.

Receber encommendas de figos artificiaes to primeiro foguelciro desia capilal.

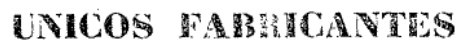

da superior tinta preta para éscrever, com o titulo

Tão boa sim, melhor não

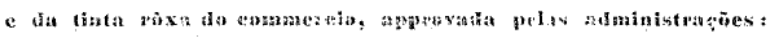

sempre tèm sortimento de garrafas, meias garrafas e potes pequenos:

is

da superior cera preta para envernizar correames de militares.

DE TUDO VEXDEM TUR ATACADO E A VAREJO

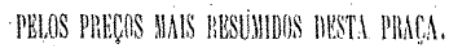

26 RUA DA QUTANDA .26

Casa Filial, rua de Vuaristo da Veiga, is.

Almanaque Laemmert, 1871 , seção de Notabilidades. ${ }^{62}$

Os tecidos de algodão eram dos principais produtos da revolução industrial inglesa. Isso se traduzia numa produção excepcional. Alice Canabrava, para o mesmo período, dá os números da produção de tecidos na Inglaterra. "Em 1861, existiam [na Inglaterra] 3.000 fábricas de tecidos, as quais possuíam 11.250 fusos e davam trabalho a cerca de 600.000 operários". ${ }^{63}$ A Inglaterra, portanto, era a maior exportadora de tecidos do mundo, com cerca de 2,8 bilhões de jardas de tecido de algodão, que saíam de seus portos para abastecer, justamente, mercados como o brasileiro. Saíam também dos portos ingleses outros produtos, como o fio simples e o fio torcido de algodão. Por isso, pode-se entender que, entre $1871 \mathrm{e}$ 1872, chegaram ao porto do Rio, 288.194 quilos de algodão em caroço e rama.

62 Disponível em: <http://brazil.crl.edu/bsd/bsd/almanak/al1871/00001302.html>. Acesso em: 26/12/2012.

63 CANABRAVA, Alice. O desenvolvimento da cultura do algodão na província de São Paulo (1861-1875). São Paulo: Edusp, 2011. p. 75. 


\begin{tabular}{|l|l|l|}
\hline \multicolumn{4}{|l|}{ Tecido } \\
\hline Algodão em caroço, rama, etc. \\
\hline País & Quant. $(\mathrm{Kg})$ & Valor \\
\hline Alemanha & 4.496 & $8: 844 \$ 000$ \\
\hline Bélgica & 411 & $822 \$ 000$ \\
\hline Confed. Argentina & 947 & $1: 894 \$ 000$ \\
\hline Estados Orientais & 800 & $1: 000 \$ 000$ \\
\hline Estados Unidos & 40 & $81 \$ 000$ \\
\hline França & 20.954 & $40: 451 \$ 000$ \\
\hline Grã-Bretanha & 255.057 & $532: 199 \$ 000$ \\
\hline Portugal & 2.941 & $5: 744 \$ 000$ \\
\hline Países indeterminados & 2548 & $5: 060 \$ 000$ \\
\hline Total & 288.194 & \\
\hline & & \\
\hline
\end{tabular}

A quantidade e, de certa forma, a variedade de tecidos importados nos dá a ideia não apenas do mercado do Rio de Janeiro, que também reexportava uma parte para outras regiões do Brasil, mas também da quantidade de roupas usadas no século XIX.

\begin{tabular}{|l|l|}
\hline \multicolumn{2}{|l|}{ Tecido } \\
\hline \multicolumn{2}{|l|}{ Obras de algodão não especificadas } \\
\hline País & Valor \\
\hline Alemanha & $52: 304 \$ 000$ \\
\hline Bélgica & $9: 473 \$ 000$ \\
\hline Confed. Argentina & $544 \$ 000$ \\
\hline Estados Orientais & $8: 078 \$ 000$ \\
\hline Estados Unidos & $821 \$ 000$ \\
\hline França & $120: 535 \$ 000$ \\
\hline Grã-Bretanha & $95: 352 \$ 000$ \\
\hline Itália & $1: 882 \$ 000$ \\
\hline Portugal & $2: 879 \$ 000$ \\
\hline Países indeterminados & $6: 295 \$ 000$ \\
\hline Total ${ }^{64}$ & \\
\hline
\end{tabular}

Não chegou aos portos cariocas apenas algodão. ${ }^{65}$ Nos navios que desembarcavam suas mercadorias, vieram também linho, seda e lã das várias procedências, conforme a classificação que o fiscal usou para taxar esses produtos nos Mapas Estatísticos. Entre a carga do linho, 88.510 quilos também vieram sem tratamento, em "bruto" ou "asseado" ou "restelado", que, provavelmente seriam trabalhados aqui. Mais uma vez, a Grã-Bretanha, com mais da metade da produção, 42.164 quilos, liderava os países exportadores, seguida pela

${ }^{64} \mathrm{Em}$ todas as tabelas têm a soma dos itens e optei por deixar as tabelas como elas estavam no original. Algumas vezes o original estava danificado ou não dava para ler a soma total dos valores.

65 Mapa geral das mercadorias importadas e despachadas para consumo anos de 1871-1872, p. 17. Disponível em: http://memoria.nemesis.org.br/. Acesso em: 20/08/2010. 
"A tirania da moda": roupas, comércio e consumo no Rio de Janeiro do século XIX

França, com 19.832 quilos. Ainda assim, o linho francês valia mais do que o inglês, 32:967\$000 réis.

\begin{tabular}{|l|l|l|}
\hline \multicolumn{4}{|l|}{ Tecido } & \multicolumn{2}{l|}{} \\
\hline Linho em bruto, assedado, restelado, etc. \\
\hline País & Quant. $(\mathrm{Kg})$ & Valor \\
\hline Alemanha & 458 & $298 \$ 000$ \\
\hline Confed. Argentina & 1.026 & $298 \$ 000$ \\
\hline Estados Orientais & 1.037 & $52 \$ 000$ \\
\hline Estados Unidos & 6.420 & $321 \$ 000$ \\
\hline França & 19.832 & $32: 967 \$ 000$ \\
\hline Grã-Bretanha & 42.164 & $24: 702 \$ 000$ \\
\hline Hespanha & 16 & $8 \$ 000$ \\
\hline Itália & 8.029 & $1: 745 \$ 000$ \\
\hline Paraguai & 184 & $9 \$ 000$ \\
\hline Portugal & 9.197 & $9: 534 \$ 000$ \\
\hline Países indeterminados & 147 & $12 \$ 000$ \\
\hline Total & 88.510 & \\
\hline
\end{tabular}

Chegaram também linhas e linho em fio torcido, para abastecer a grande quantidade de armarinhos, casas de bordados e armazéns que vendiam produtos para as costuras de casa e de pequenos ateliês. Na tabela abaixo, vemos que foram 59.447 quilos no total e a maioria, mais uma vez, da Grã-Bretanha, 29.567 quilos.

\begin{tabular}{|c|c|c|}
\hline \multicolumn{3}{|l|}{ Tecido } \\
\hline \multicolumn{3}{|c|}{$\begin{array}{l}\text { Linho em fio torcido ou linhas de qualquer } \\
\text { qualidade }\end{array}$} \\
\hline 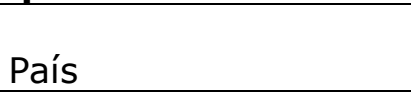 & $\begin{array}{l}\text { Quant. } \\
\text { (Kg) }\end{array}$ & Valor \\
\hline Alemanha & 6.036 & $6: 029 \$ 000$ \\
\hline Bélgica & 3.904 & $7: 797 \$ 000$ \\
\hline Confed. Argentina & 4 & $2 \$ 000$ \\
\hline Estados Orientais & 172 & $344 \$ 000$ \\
\hline França & 15.448 & $10: 886 \$ 000$ \\
\hline Grã-Bretanha & 29.567 & $35: 374 \$ 000$ \\
\hline Paraguai & 2 & $1 \$ 000$ \\
\hline Portugal & 4.312 & $8: 403 \$ 000$ \\
\hline Países indeterminados & 2 & $3 \$ 000$ \\
\hline Total & 59.447 & \\
\hline
\end{tabular}


"A tirania da moda": roupas, comércio e consumo no Rio de Janeiro do século XIX

\begin{tabular}{|l|l|l|}
\hline \multicolumn{3}{|l|}{ Tecido } \\
$\begin{array}{l}\text { Aniagem, canhamaço, tecidos crus de fio de } \\
\text { estopa }\end{array}$ & $\begin{array}{l}\text { Quant. } \\
(\mathrm{Kg})\end{array}$ & Valor \\
\hline País & 374.775 & $224: 697 \$ 000$ \\
\hline Alemanha & 93 & $56 \$ 000$ \\
\hline Bélgica & 43.699 & $26: 220 \$ 000$ \\
\hline Estados Orientais & 25 & $15 \$ 000$ \\
\hline Estados Unidos & 145.051 & $95: 106 \$ 000$ \\
\hline França & 4.061 .439 & $2453: 869 \$ 000$ \\
\hline Grã-Bretanha & 790 & $474 \$ 000$ \\
\hline Portugal & 5.110 & $3: 066 \$ 000$ \\
\hline Suécia & 19.949 & $14: 487 \$ 000$ \\
\hline Países indeterminados & 4.650 .931 & \\
\hline Total & & \\
\hline
\end{tabular}

O linho, por exemplo, como se percebe pela tabela abaixo, era usado em meias, luvas, gravatas e ligas e vinha de países como Alemanha, Grã-Bretanha, Itália e, principalmente nesse caso, a França. A lã era usada para os mesmos fins do linho e vinha principalmente da Inglaterra.

Não fazia muitos anos que a chegada da família real portuguesa ao Rio de Janeiro havia mudado a maneira com que seus habitantes se vestiam - cerca de 30 anos apenas. Disseram dois viajantes no início do século:

Apesar do calor $[\ldots]$ a gente do povo [...] usa uns casacos pesados e felpudos. O mesmo fazem as mulheres, que ainda se cobrem de véus pretos [...]. De outro modo. Vestem-se elas, brasileiras e portuguesas, de sedas e tafetás; enquanto que as negras e mulatas usam tecidos grosseiros de lã em cor preta. ${ }^{66}$

Os tecidos que começavam a ser importados transformavam-se em casacos como os descritos pelos dois viajantes estrangeiros em 1819. Em algumas décadas, as mudanças na maneira de fabricar e vender tecidos na Inglaterra modificaram de forma substancial o modo de se vestir no Brasil. Mas a Grã-Bretanha não era o único país a tentar vender tecidos no Brasil.

Por isso, no jogo do comércio mundial do período, outras nações tinham uma participação significativa. O Paraguai, nos anos de 1845-1849, aparece várias vezes como um exportador menor, mas sempre presente - foram 20 quilos de algodão em fios simples; 50 quilos de panos de algodão cru, curado e lavrado; 386 quilos de morim, madapolão, bretanha, riscadinho e chita; 184 quilos de linho em bruto, asseado, restelado; 6 quilos de baeta,

66 LEITHOLD, Theodor von e RANGO, Ludwig von. O Rio de Janeiro visto por dois prussianos em 1819. São Paulo: Companha Editora Nacional, 1966. p. 28. 
"A tirania da moda": roupas, comércio e consumo no Rio de Janeiro do século XIX

baetilha, baetão e flanela em peças e, surpreendentemente, já que era um produto sofisticado, $400 \$ 000$ réis em rendas em peças e cortes. ${ }^{67}$

A França também era uma exportadora de tecidos significativa - e aparece nas balanças comerciais em segundo ou terceiro lugares do todo. O que chama a atenção, contudo, é a importância francesa em produtos como rendas, cujas exportações totalizaram $33.387 \$ 000$ contos de réis, enquanto a Grã-Bretanha exportou 6:397\$000 contos de réis. Nos acessórios, como veremos mais à frente, a França competia com a Inglaterra quase que de igual para igual - muitos acessórios franceses valiam mais dos que os ingleses, principalmente nos produtos femininos. ${ }^{68}$

Roupas prontas, de todas as espécies, eram poucas as que chegavam por aqui. A França era a maior exportadora de roupas prontas, com 1.406:280\$000 réis em roupas prontas de algodão, 78:037\$000 em roupas de seda, 192:494\$000 em roupas de linho e 281:446\$000 em roupas de lã. No total, foram 1.958:257\$000 contos de réis de roupas prontas que entraram legalmente pelo porto do Rio de Janeiro entre $1871 / 72$. Para se ter uma ideia, esse montante equivalia ao valor de mais de mil casas na região do Carandiru e Morro de Santana, em São Paulo, em $1881,{ }^{69}$ ou cerca de 830 escravos, vendidos no interior paulista, em $1878 .^{70}$

\begin{tabular}{|l|l|}
\hline \multicolumn{2}{|l|}{ Tecido } \\
\hline Roupas diversas de algodão \\
\hline País & Valor \\
\hline Alemanha & $105: 330 \$ 000$ \\
\hline Bélgica & $39: 275 \$ 000$ \\
\hline Confed. Argentina & $12: 616 \$ 000$ \\
\hline Estados Orientais & $30: 165 \$ 000$ \\
\hline Estados Unidos & $60 \$ 000$ \\
\hline França & $1.406: 280 \$ 000$ \\
\hline Grã-Bretanha & $707: 326 \$ 000$ \\
\hline Espanha & $195 \$ 000$ \\
\hline Itália & $7: 502 \$ 000$ \\
\hline Paraguai & $604 \$ 000$ \\
\hline Portugal & $4: 436 \$ 000$ \\
\hline Suécia & $24 \$ 000$ \\
\hline Países indeterminados & $64: 664 \$ 000$ \\
\hline Total & \\
\hline
\end{tabular}

67 Mapa geral das mercadorias importadas e despachadas para consumo anos de 1845-1849, p. 17. Disponível em: <http://memoria.nemesis.org.br/>. Acesso em: 27/08/2012.

68 Entre os acessórios de moda mais comuns no século XIX estão os chapéus, as luvas, as bengalas, os relógios, as joias.

69 OLIVEIRA, Maria Luzia Ferreira de. Entre a casa e o armazém. São Paulo: Alameda Casa Editorial, 2005. p. 325.

70 MOTTA, José Flávio. Escravos daqui, dali e de mais além: o tráfico interno de cativos na expansão cafeeira paulista. São Paulo: Alameda Casa Editorial, 2012. p. 255. 


\begin{tabular}{|l|r|}
\hline \multicolumn{2}{|l|}{ Tecido } \\
\hline \multicolumn{2}{|l|}{ Roupa de seda diversa } \\
\hline País & Valor \\
\hline Alemanha & $2: 356 \$ 000$ \\
\hline Bélgica & $210 \$ 000$ \\
\hline Confed. Argentina & $500 \$ 000$ \\
\hline Estados Orientais & $1: 655 \$ 000$ \\
\hline França & $78: 037 \$ 000$ \\
\hline Grã-Bretanha & $45: 058 \$ 000$ \\
\hline Portugal & $12: 042 \$ 000$ \\
\hline Países indeterminados & $4: 979 \$ 000$ \\
\hline Total & \\
\hline
\end{tabular}

\begin{tabular}{|l|r|}
\hline \multicolumn{2}{|l|}{ Tecido } \\
\hline Roupas de linho & Valor \\
\hline País & $4: 821 \$ 000$ \\
\hline Alemanha & $1: 540 \$ 000$ \\
\hline Bélgica & $3: 508 \$ 000$ \\
\hline Estados Orientais & $192: 494 \$ 000$ \\
\hline França & $110: 573 \$ 000$ \\
\hline Grã-Bretanha & $585 \$ 000$ \\
\hline Itália & $240 \$ 000$ \\
\hline Paraguai & $3: 479 \$ 000$ \\
\hline Portugal & $9 \$ 000$ \\
\hline Suécia & $8: 393 \$ 000$ \\
\hline Países indeterminados & \\
\hline Total & \\
\hline
\end{tabular}

\begin{tabular}{|l|r|}
\hline Tecido \\
\hline Roupa de lã diversas & Valor \\
\hline País & $114: 453 \$ 000$ \\
\hline Alemanha & $9: 636 \$ 000$ \\
\hline Bélgica & $4: 970 \$ 000$ \\
\hline Confed. Argentina & $14: 698 \$ 000$ \\
\hline Estados Orientais & $281: 446 \$ 000$ \\
\hline França & $157: 190 \$ 000$ \\
\hline Grã-Bretanha & $194 \$ 000$ \\
\hline Itália & $83 \$ 000$ \\
\hline Paraguai & $2: 105 \$ 000$ \\
\hline Portugal & $41: 472 \$ 000$ \\
\hline Países indeterminados & \\
\hline Total & \\
\hline
\end{tabular}


Ao longo do século XVIII e no início do século XIX, a França desenvolveu um complexo sistema de ateliês e pequenas confecções de roupas prontas, por isso explica-se o fato de a maior quantidade de roupas prontas ter vindo de lá. Daniel Roche vai explicar o fenômeno dizendo que a França desenvolveu

[...] uma indústria de roupa de luxo, concentrada em Paris, com uma tradição, clientes e grande interesses em jogo. Para sobreviver, ela precisava manter um fluxo de roupas novas e, para expandir, necessitava acelerar a frequência com que eram substituídas. ${ }^{71}$

Dessa forma, a indústria de roupas prontas se expandiu conforme mudanças e práticas desenvolvidas a partir da Revolução Industrial. Michelle Perrot vai mostrar como, no século XIX, essa indústria de moda feita em casa e em ateliês conheceu uma expansão considerável ainda mais depois da popularização da máquina de costura a partir de 1860 . Escreveu a historiadora:

\begin{abstract}
Esse fenômeno está ligado ao desenvolvimento da indústria de vestuário em série, a confecção, e responde ao lugar real e simbólico do vestuário de roupa branca, grande forma de consumo do século XIX. Muito racionalizada, essa indústria associava fabricação em domicílio das peças, com uma intensa divisão do trabalho, e montagem em ateliês de centros urbanos. ${ }^{72}$
\end{abstract}

No Rio de Janeiro de d. Pedro II, a importação de tecidos da Inglaterra ou da França ajudou a montar uma das indústrias mais lucrativas do século XIX, a de confecção de roupas. O movimento da alfândega carioca mostra quanto tecido e acessórios ligados à moda foram importados no período. Uma vez no Brasil, os tecidos eram transformados em roupas, símbolos de status de uma elite em formação.

Movendo-se com a economia do Rio de Janeiro, a moda espelhava as escolhas de consumo da classe dominante. Em uma sociedade que ainda estava se formando, como o Brasil no qual viveu d. Pedro II, nos quais os membros da sociedade não se encontram suficientemente caracterizados, diferenciando-se entre si por uma tradição de usos, costumes e maneiras próprias, a posse de riqueza é a grande modificadora da estrutura social. A posse da riqueza, portanto, deveria ser traduzida em símbolos de riqueza aparentes, como as roupas. Os títulos de nobreza no Brasil eram distribuídos e não herdados - assim, formou-se uma elite de nobres na Corte do Rio do Janeiro.

As roupas passaram a afirmar as distinções sociais na sociedade brasileira com bastante clareza. Com a expansão das exportações inglesas de tecidos, resultado das modificações dos processos que culminariam na Revolução Industrial, e a abertura dos portos no Rio de Janeiro, uma quantidade cada vez maior de tecidos e acessórios ligados à moda começavam a chegar

${ }^{71}$ ROCHE, Daniel. A cultura das aparências: uma história da indumentária. São Paulo: Senac, 2007. p. 57.

72 PERROT, Michelle. As mulheres ou os silêncios da história. Bauru: Edusc, 2005. p. 233-234. 
"A tirania da moda": roupas, comércio e consumo no Rio de Janeiro do século XIX ao Rio e a serem revendidos em lojas e ateliês da cidade. Se, nos primeiros anos do império e na época da regência, as vestimentas eram feitas predominantemente em casa, com a popularização das máquinas de costura, entre as décadas de 1850 e 1870, uma série de ateliês de costura foram abertos, no Rio de Janeiro, por estrangeiros interessados em vestir a nova elite carioca.

Joana de Moares Monteleone: Doutora em História Econômica pela Universidade de São Paulo e autora de Sabores Urbanos: alimentação, sociabilidade e consumo. São Paulo, 18281910 (São Paulo: Alameda Casa Editorial, 2015). 